\title{
Scientific Analysis on the Accessory Ornament of Woolen Tapestry Curtain in Seoul Museum of Craft Art
}

\author{
Jaewan Choi ${ }^{1{ }^{*}}$, Jangjon Lee ${ }^{2}$, Boyeon $\mathrm{An}^{3}$ \\ ${ }^{1}$ West Sea Cultural Heritage Division, National Research Institute of Maritime Cultural Heritage, Taean, Chungnam 32132, Korea \\ ${ }^{2}$ High Heritage Care, Daejeon 34013, Korea \\ ${ }^{3}$ Cultural Heritage Conservation Science Center, National Research Institute of Cultural Heritage, Daejeon 34122, Korea
}

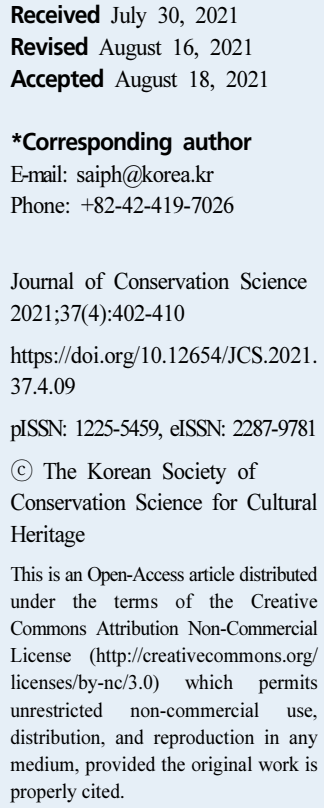

\begin{abstract}
Woolen tapestry curtains possessed by the Seoul Museum of Craft Art were used to hung on the wall or used for carpets in the winter season in the late Joseon dynasty. Since similar artifacts were only used for the curtain as functional aspects, woolen tapestry curtains were a rare case. In this study, scientific analysis on the accessory ornament of woolen tapestry curtains such as components of metal accessories and frame bar were conducted with the microscope, $\mathrm{p}-\mathrm{XRF}$, and SEM. Result of frame bar pigments, organic pigments such as ink stick were likely been used in woolen tapestry curtain 1 . In woolen tapestry 2, lead red (Minium) was used in the frame bar. The result of metal parts, copper, and zinc were analyzed by $\mathrm{p}$-XRF. This suggests that metal accessories were crafted using brass. Frame bar of woolen tapestry curtain 2 was made of soft pine (Pinus spp.) analyzed with the scanning electron microscope. Artifacts like woolen tapestry curtains are rare in Korea and scientific analysis databases were scarce, so it is important to construct components analysis data of woolen tapestry curtains. It is expected that additional scientific analysis and interpretation on the artifact's crafting technique can be merged with the analytical data gathered in this study to be utilized on the conservation and restoration of not only woolen curtains but curtain artifacts of the late Joseon dynasty in general.
\end{abstract}

Key Words Wood species identification, Pigment analysis, Woolen tapestry, Minium, Brass, Soft pine

\section{INTRODUCTION}

Tapestry curtains are drapes hung around a room to keep out external air, and are mostly made of wool or silk for winter use. They are made to lean on the wall and hang from the side nearest to the ceiling and were used in Korea since Three States period (Shin, 1995). Moreover, curtains were considered luxury only used by the upper class for a long time, and several remaining artifacts from late Joseon dynasty are under the possession of Seoul Museum of Craft Art, Seoul Museum of History, and National Folklore Museum of Korea (Seoul Museum of History [SMH], 2006; e-Museum, n.d.).
Most curtains structures are composed of frame bar and metal accessory ornaments, and are decorated by crafting them with silk weaving and applying appliqué on bat pattern, character 'Hui (喜)' pattern and character 'Su (壽)' pattern. Meanwhile, the only woolen tapestry curtains are the two artifacts possessed by Seoul Museum of Craft Art. Similarly, accessories such as metal accessories and frame bar used to hang vertically on top, middle, and bottom door or window frames are present, and fabric is composed of Modam (Woolen tapestry) crafted from cotton and wool. Especially, in terms of technique, patterns on the fabric were crafted using tapestry prior to painting, which is called Chaedam 
(Overpainted woolen tapestry) (Shim, 2016). A similar artifact is Joseoncheol (Joseon's carpet) owned by Yoshida Gojiro from Kyoto, Japan (Kyungwoon Museum, 2016). However, Joseoncheol was used as a rug without any accessories which is a significant difference from the woolen tapestry curtain.

Studies on woolen tapestry curtain by Min (1992) focused on the fabric, pattern, and weaving technique rather than its functions as a curtain due to the rarity of woolen fabric from Joseon dynasty (Shim, 2016; An et al., 2019). Rugs, drapes, and curtains of Joseon dynasty may share similar crafting techniques but their fundamental usage differ according to the existence of accessories.

This study is on a rare case of woolen tapestry curtain possessed by the Seoul Museum of Craft Ar. Accessories of woolen tapestry curtain, which is significant as it examines the functional and technological aspects of the curtain. Specifically, scientific analysis on the frame bar pigments, metal accessories and wood species identification were conducted. This study will shed new light on the accessories of curtains from late Joseon dynasty and provide scientific analysis on the material of the accessories. Moreover, this study is expected to be applicable of fundamental data for the conservation and restoration of Joseon curtains in the future.

\section{ANALYTICAL SUBJECT AND METHOD}

\subsection{Subject}

Understanding of the similar case of woolen tapestry, Unhyeongung curtain artifact crafted in 19th $\sim 20$ th century

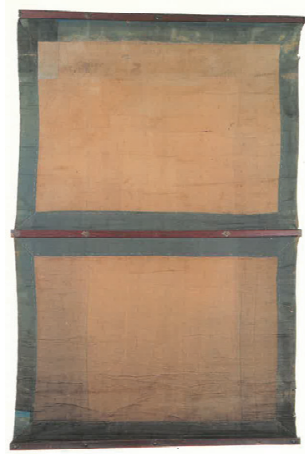

(A)

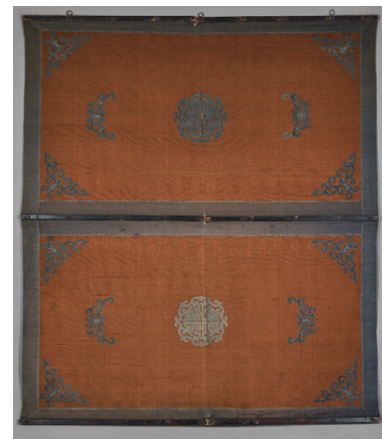

(B)

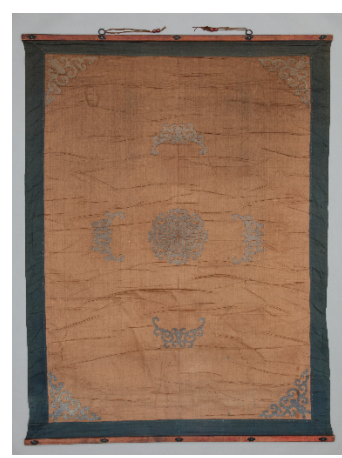

(C)

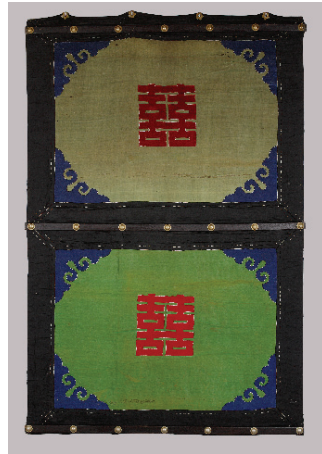

(D)

Figure 1. Silk curtain of late Joseon dynasty period. (A) Seoul Museum of Craft Art. (B) Seoul Museum of History. (C) \& (D) National Folklore Museum. 


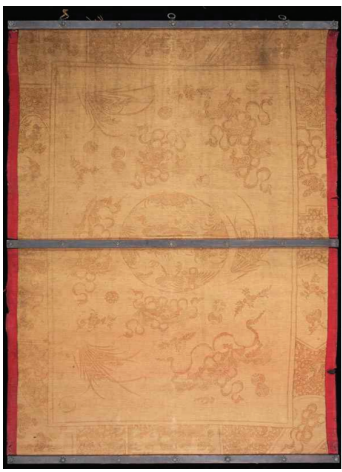

(A)

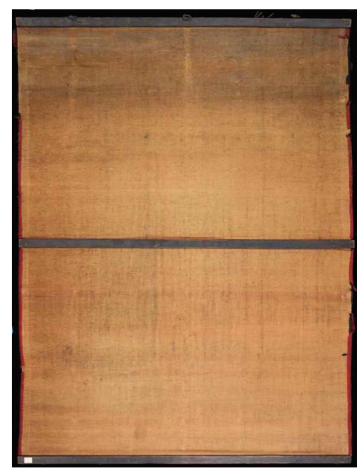

(B)
Figure 2. Woolen tapestry curtain 1. (A) Front side. (B) Back side.

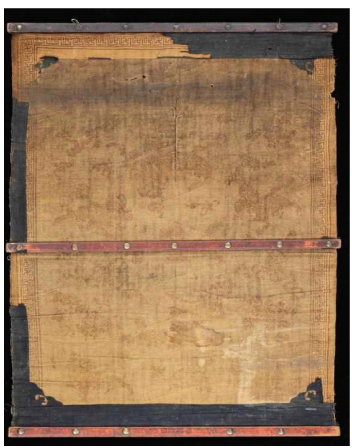

(A)

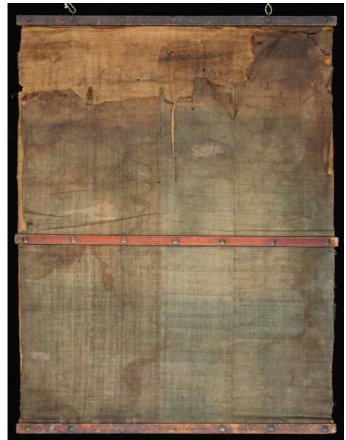

(B)
Figure 3. Woolen tapestry curtain 2. (A) Front side. (B) Back side.

for weft (An et al., 2019), and there are accessories such as frame bar and metal accessories on the top, middle, bottom parts to hang the curtain on a door or window frame. Woolen tapestry curtain 1 is $216 \mathrm{~cm}$ in length and $156 \mathrm{~cm}$ in width as can be seen in Figure 2, and woolen tapestry curtain 2 is $181 \mathrm{~cm}$ in length and $129 \mathrm{~cm}$ in width as can be seen in Figure 3. They vary by $30 \mathrm{~cm}$ in size, and the color of the frame bar also varies. Woolen tapestry curtain 1's frame bar is black whereas the frame bar of woolen tapestry curtain 2 is black at the top but painted red at the middle and bottom. frame bars are $4.5 \mathrm{~cm}$ wide in and $1.8 \mathrm{~cm}$ thick after fastening the clothing. In the case of metal accessories, 7 metal accessories are stuck on each frame bar, and hook shaped ones are attached at both ends of the top to hang the curtains. metal accessories's diameter is approximately $3.5 \mathrm{~cm}$ long.

In this study, with the subject set as the frame bar and metal accessories of woolen tapestry curtain, the pigments on the surface of frame bar and main components of metal accessories were examined using a digital microscope and $\mathrm{p}$-XRF. Moreover, a fragment of frame bar that naturally detached from woolen tapestry curtain 2 was used to conduct wood species identification.

\subsection{Analytical method}

A high performance multi-digital microscope (DG-3, Scalar, JPN) was used to observe the pigment particles on the surface of frame bar. Furthermore, a handheld XRF analyzer (Delta Professional, Olympus, USA) was used to analyze the main composing elements of pigments and metal

Table 1. Scientific analysis point of woolen tapestry curtains

\begin{tabular}{|c|c|c|c|}
\hline No. & Classification & Sample name & Sample number \\
\hline 1 & Metal accessory & \multirow{2}{*}{ Woolen tapestry curtain 1} & 1 \\
\hline 2 & Frame bar pigment & & 2 \\
\hline 3 & Metal accessory & \multirow{9}{*}{ Woolen tapestry curtain 2} & 3 \\
\hline 4 & Metal accessory & & 4 \\
\hline 5 & Metal accessory & & 5 \\
\hline 6 & Metal accessory & & 6 \\
\hline 7 & Frame bar pigment & & 7 \\
\hline 8 & Frame bar pigment & & 8 \\
\hline 9 & Frame bar pigment & & 9 \\
\hline 10 & Wood species identification & & 10 \\
\hline 11 & Wood species identification & & 11 \\
\hline
\end{tabular}



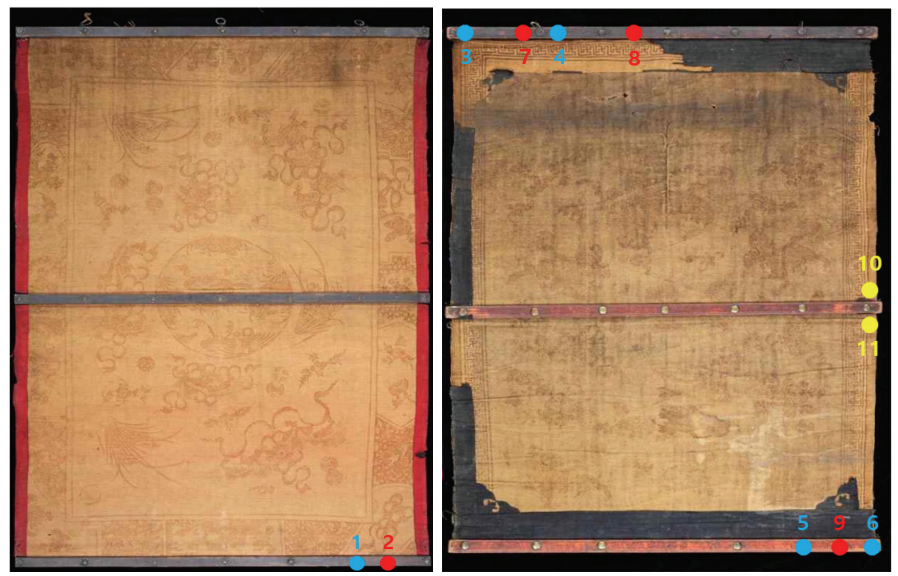

Figure 4. Analysis points (Blue: Metal parts, Red: Pigment parts, Yellow: Wooden parts).

accessories. The analytical conditions of XRF was $50 \mathrm{kV}$, $200 \mu \mathrm{A}$, and 15 seconds with soil mode and alloy mode simultaneously analyzed. The type of pigment and metal components were derived based on the data from XRF analysis (Table 1, Figure 4).

Wood species identification were conducted using a fragment of frame bar retrieved from the central frame bar of woolen tapestry curtain 2. Sample was made in a hexahedral shape to expose vertical, horizontal, and diagonal cross-sections using a stainless razor blade (ST-300, Dorco, KOR) and the tissues were observed. Three cross-sections of each tissue were observed using an optical microscope (Eclipse Ni-E, Nikon, JPN) to produce specimen. Each specimen was fixated on an aluminium holder using carbon tape and observed using a scanning electron microscope (TM-3000, Hitachi, JPN) to record photos that could be used to identify the wood species. The photos were taken at acceleration voltage of $15 \mathrm{kV}$, and $120 \sim 800$ magnification rate. Preceding studies and database on wooden species identification were referenced.

\section{ANALYTICAL RESULTS}

\subsection{Analytical results of frame bar pigments}

Status and main elements at four locations were analyzed using digital microscope and handheld XRF analyzer to investigate the pigments used on woolen tapestry curtain's frame bar. Filming the two woolen tapestry curtains using a digital microscope showed no particles on the background color were found. Black particles were observed at the black pigments of frame bar from the woolen tapestry curtain 1 . And the red, dark red, and deep color red particles were partially confirmed in frame bar from woolen tapestry curtain 2 (Table 2).

XRF analysis was conducted by first checking the components of the background and bottom layer and analyzing the main elements based on the obtained data. Traces of $\mathrm{Ca}, \mathrm{K}$, and $\mathrm{Fe}$ were detected as major elements from the background and bottom layer. As no major component was detected in the background layer for frame bar of woolen tapestry curtain 1, organic pigment has likely been used. Since, black colors were painted in frame bar and carbon were detected by XRF, assumed that ink stick might be used for the black pigment (Lee et al., 2017). In the frame bar of woolen tapestry 2 , lead $(\mathrm{Pb})$ was detected from red and dark red pigments, suggesting the usage of minium $\left(\mathrm{Pb}_{3} \mathrm{O}_{4}\right)$ (National Research Institute of Cultural Heritage [NRICH], 2018). Minium depicts color slightly brighter than orange and is called red lead. XRF analysis results of Jongmyo Shinyeojuryeom, from a similar period, confirmed $\mathrm{Pb}$ as well as $\mathrm{Hg}$ and $\mathrm{S}$ from its red painting on the surface, signifying the usage of ruddle along with lead tetroxide (Minium) and cinnabar (Kim, 2012).

\subsection{Analytical results of metal accessories}

Five metal accessories from woolen tapestry curtains were shot at measuring points using a digital microscope and their main elements were confirmed using a handheld XRF analyzer 
Table 2. Component analysis result of metal accessory and frame bar pigment

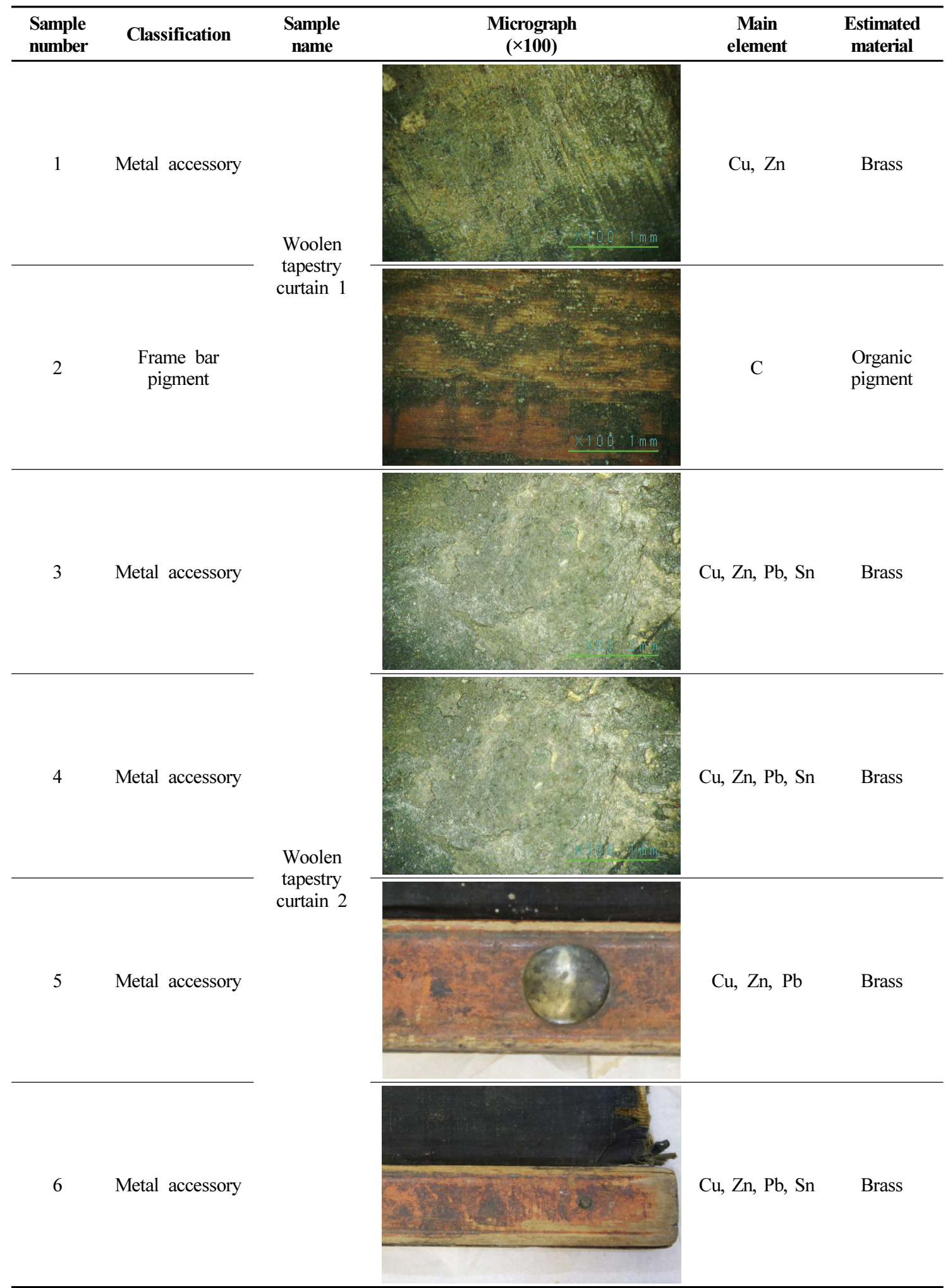




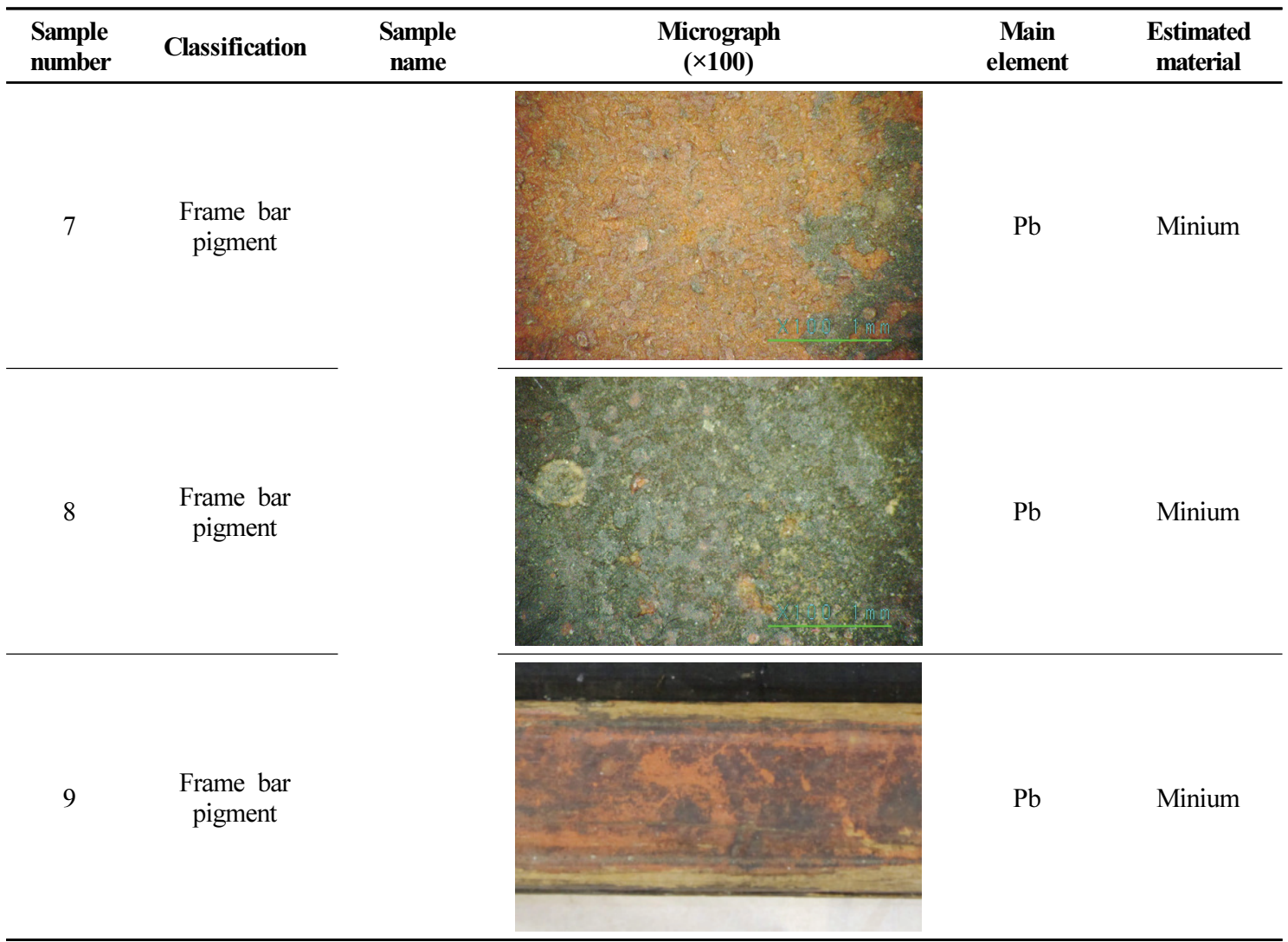

(Table 2). XRF analysis results showed copper and zinc from metal accessories of both curtains. This suggests that metal accessories was crafted using brass, an alloy of copper and zinc (Lee and Jeon, 2015). Brass is an alloy made by adding zinc to copper, and is an important copper alloy along with bronze. It has beautiful color, is easy to cast, has superior hardness and strength as well as malleability, making it suitable for crafting thin films or wires, and ultimately used for various ornaments. This can also be confirmed from Geumjeonji (Decorating gold paper) of Shinyeojuryeom possessed by Jongmyo which dates to late 19th century to early 20th century and metal ornaments of leather belt possessed by Chuncheon National Museum (Park et al., 2010; Kim, 2012).

According to a study by Kim (2008), brass shares the same meaning as pisolite, Waeyeon (Japanese zinc), zinc, and Hamseok (Thin sheet of iron with zinc plated on the surface). Myeongmulgo (名物考) (Examination of famous objects), a document from Joseon dynasty, designates a pisolite as brass. According to Ojuyeonmunjangjeonsango (五洲衍文長箋散 稿, Waeyeon signifies zinc in main China whereas Japanese call them zinc and Korea refers to it as Hamseok (含錫) (Kim, 2008).

\subsection{Results of wooden species analysis}

Wooden species analysis was conducted on two samples that naturally detached from the central crossing bar of woolen tapestry curtain 2. Cross section was composed of coniferous trees with tracheid being the principal cell, Transition from earlywood to latewood were gradual and Growth ring boundaries were distinct. Axial intercellular canal was difficult to observe as sample size was small. Tracheid in the radial section showed one row of bordered pit in the inner wall, while radial structure was composed of ray parenchyma cells and ray tracheids. In the cross-field pitting, inside ray parenchyma cell was in the shape of window-like pit, while the inner wall of ray tracheid was flat without ray tracheids dentate. Tangential section showed a single layer ray composition, along with fusiform ray located at the center of radial intercellular. Such characteristics are distinguishable features of Pinaceae plants (Pinus spp.) and 


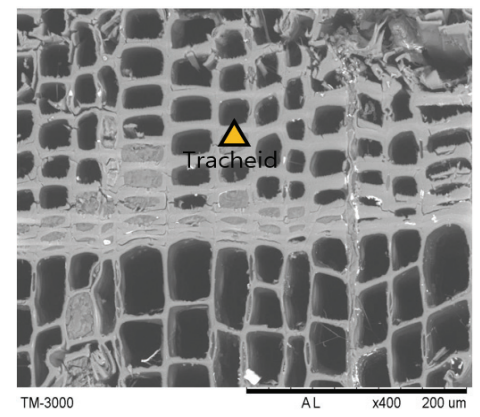

(A) Cross section $\times 180$

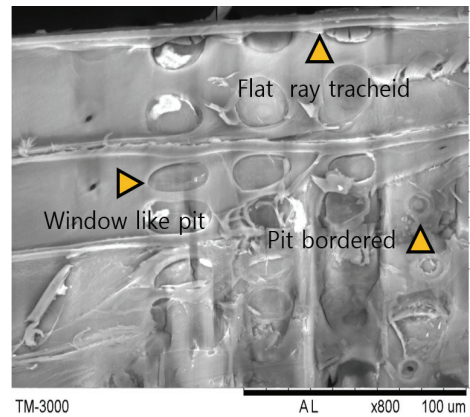

(B) Radial section $\times 800$

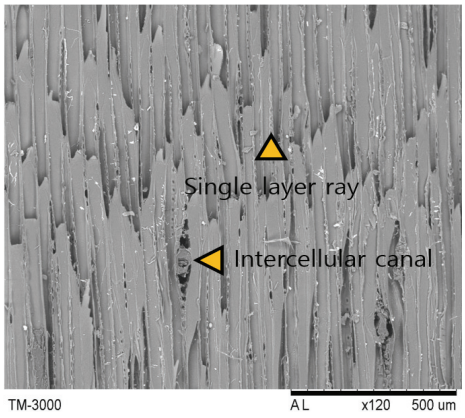

(C) Tangential section $\times 120$

Figure 5. SEM image of woolen tapestry curtain 2 sample 10.

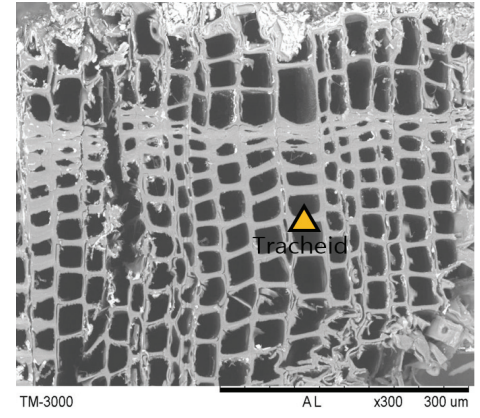

(A) Cross section $\times 300$

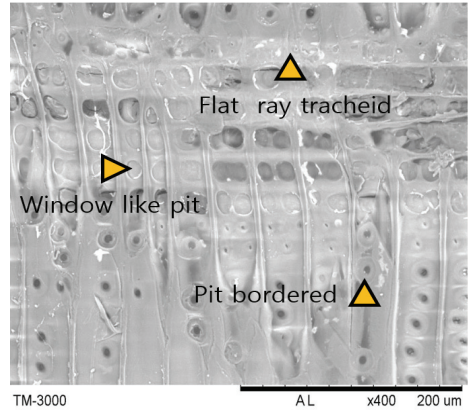

(B) Tangential section $\times 400$

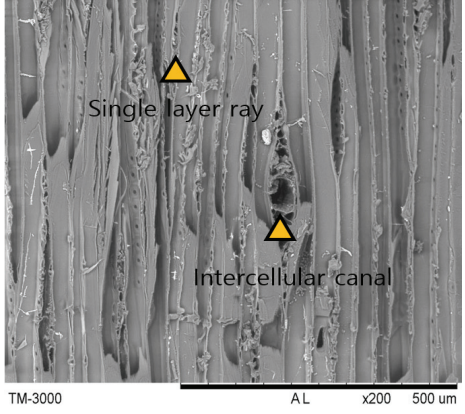

(C) Tangential section $\times 120$

Figure 6. SEM image of woolen tapestry curtain 2 sample 11.

soft pine (Park, 1987; National Folklore Museum, 2004; Lee, 1997a; Lee, 1997b; Lee, 1997c; Eom, 2015).

Due to the above traits, the specimen was identified as soft pine in the genus Pinus and in the family of Pinaceae (Figure 5, 6). Pinus koraienesis S. et $\mathrm{Z}$. is a typical native soft pine, and is known to be located above central Korean peninsula (Eom, 2015). Meanwhile, frame bar has been identified as a soft pine from Hanging Painting of Sudosa Temple (Rocana Buddha) which were made in 1704 (Kim et al., 2016), but there does not seem to be many cases where soft pine was used on frame bar.

\section{DISCUSSION AND CONCLUSION}

Woolen tapestry curtain 1 and 2 are curtain artifacts made from woolen tapestry composed of cotton warp and wool weft and hung on doors or windows using accessories. Fabric was painted using pigment and patterns were depicted in tapestry. frame bar and metal accessories were attached as accessories which were analyzed through digital microscope, XRF analysis, and wooden species analysis. Analytical results showed that frame bar of woolen tapestry curtain 1 is organic pigment as main component was undetected through XRF analysis, and is considered to be a black paint mostly composed of carbon such as ink stick as it is black and particles can be confirmed by observing through a digital microscope. Red particles were observed from the red and dark red areas of woolen tapestry curtain 2, which were confirmed to be mainly lead, suggesting the usage of lead red (Minium). XRF analysis results of metal accessories showed that copper and zinc were mainly used on all metal accessories. This implies the usage of brass, an alloy of copper and zinc. Wooden species analysis was conducted on two samples retrieved from woolen tapestry curtain 2's central frame bar which identified the specimen as soft pine (Pinus spp.) Frame bar is considered to have been crafted using soft pine when making woolen tapestry curtain 2 . Generally in Korea, hard pines and soft pines are mostly 
commonly used for wooden artifacts. In appears that further specimen analysis is required on woolen tapestry curtain 1 and 2 to confirm what type of trees were used.

Artifacts like woolen tapestry curtain are rare in Korea and analysis on its material is scarce, so scientific analysis of wooden tapestry curtain is significant as it examined that materialistic traits of the artifact and confirmed its crafting method. Moreover, the pigments used on frame bar was confirmed as well as the main elements of metal accessories. Inorganic pigment such as lead red (Minium) were confirmed using XRF analysis but organic pigments need to be further analyzed using organic analysis such as FT-IR, HPLC/MS or pyrolysis GC/MS. Also, confirmation on whether the metal accessories (Brass) and frame bars (Soft pine) has been reprocessed is necessary. It is expected that additional scientific analysis and interpretation on the artifact's crafting technique can be merged with the analytical data gathered in this study to be utilized on the conservation and restoration of not only woolen curtains but curtain artifacts of late Joseon dynasty in general.

\section{ACKNOWLEDGEMENT}

This study is part of the research project $\ulcorner$ Conservation and Research on Organic Cultural Heritage」 conducted by National Research Institute of Cultural Heritage, Cultural Heritage Conservation Science Center. Special gratitude is expressed toward National Research Institute of Cultural Heritage and Seoul Museum of Craft Art for allowing the analysis of woolen tapestry curtains.

\section{REFERENCES}

An, B.Y, Lee, J.J. and Lee, R.M., 2019, Textile analysis of woolen tapestry curtain in Seoul Museum of Craft Art. Journal of Conservation Science, 35(6), 612-620. (in Korean with English abstract)

e Museum, (n.d.), Traditional curtain [房帳]. In National Museums Search Portal, National Museum of Korea. http://www.emuseum.go.kr/headerSearch?category $=$ \&ro ws $=20$ \&pageNum $=1$ \& radioSearchCheck $=$ unifiedSearch\& headerSearch $=\&$ keyword $=\% \mathrm{~EB} \% \mathrm{~B} 0 \% \mathrm{~A} \% \mathrm{EC} \% 9 \mathrm{E} \% \mathrm{~A} 5$ $\&$ keywordHistory $=\% \mathrm{~EB} \% \mathrm{~B} 0 \% \mathrm{~A} 9 \% \mathrm{EC} \% 9 \mathrm{E} \% \mathrm{~A} 5$, August 10, 2021.

Eom, Y.G., 2015, Wood anatomy of Korean Species. Media Wood Ltd., Seongnam. (in English and Korean)
Huh D.H., 2006, Korean Gyubang culture. Hyeonamsa, Seoul. (in Korean)

Kim, S.K., 2008, Duseok and Duseokjang in Joseon period, Life Cultural Studies, Vol. 23, National Folklore Museum. (in Korean)

Kim, S.Y., 2012, Study on Shinyojuryeom through historical documents and scientific analysis. Journal of the Korean Society of Costume, 62(8), 19-27. (in Korean with English abstract)

Kim, S.K., Choi, J.W. and Jeong, A.R., 2016, Study regarding species identification for Hanging Paintings and Hanging Painting Storage Boxes in Joseon Dynasty. Journal of Conservation Science, 32(4), 535-548. (in Korean with English abstract)

Kyungwoon Museum, 2016, Special Exhibition: What is Joseoncheol (in Korean)

Lee, J.J., Ahn, J.Y., Yoo, Y.M., Lee, K.M. and Han, M.S., 2017, Diagnosis of coloration status and scientific analysis for pigments to used large Buddhist Painting (Gwaebultaeng) in Tongdosa Temple. Journal of Conservation Science, 33(6), 431-442. (in Korean with English abstract)

Lee, J.S. and Jeon, I.H., 2015, Study on the Manufacturing Techniques of Metallic Ornament of Treasure 930, the Staffs of Yi Gyeong-seok. Journal of Conservation Science, 31(3), 309-318. (in Korean) (in Korean with English abstract)

Lee, P.W., Seoul National University, 1997a, Properties and uses of Korean Wood I. (in Korean)

Lee, P.W., Seoul National University, 1997b, Properties and uses of Korean Wood II. (in Korean)

Lee, W.Y., 1997c, Anatomy Structure of Korean Wood. (in Korean)

Min, G.Z., 1992, Excavation of Korean Traditional Textile Products -Focused on Handmade Products (Carpet and Rug)-. Journal of the Korean Society of Costume, 18, 21-34.

National Folklore Museum of Korea, 2004, Species identification and dendrochronology of Wooden Furniture. (in Korean)

National Research Institute of Cultural Heritage, 2018, Scientific analysis of cultural heritage. (in Korean)

Park, S.J., 1987, Hyangmunsa, Wooden Structure and Characteristic of Wood. (in Korean)

Park, S.W., Kwon, H.H., Yu, HS. and Jo, K.M., 2010, Scientific conservation of Seodae of the Chuncheon National Museum. Conservation Science in Museum, 11, 31-42. (in Korean with English abstract)

Seoul Museum of History, 2006, Unhyeongung Collection IV. Shin, Y.H., 1995, Seoul Cheongryongsa Temple Guardian 
Painting. In Encyclopedia of Korean Culture, The Academy of Korean Studies. http://encykorea.aks.ac.kr/ Contents/SearchNavi?keyword=\%EB\%B0\%A9\%EC\%9E $\% A 5 \&$ ridx $=2 \&$ tot $=19$, August 10, 2021.

Shim, Y.O., 2016, A study on expressive technique and design of Joseon's carpet through 'Che-dam Bang Jang' owned by Museum of Korean Embroidery. Journal of Traditional Korean Culture Studies, 18, 147-179. (in Korean) 